\title{
A Tribute to Judge John Daniel Tinder
}

\author{
Chief Judge Richard L. YounG*
}

In the United States, a presidential appointment, be it to a cabinet position, an Article III judgeship, or another high office, is a reflection of the high esteem in which the appointee is held. The Honorable John Daniel Tinder received three such appointments in his career: from President Ronald Reagan to serve as U.S. Attorney for the Southern District of Indiana (1984); a second appointment from President Reagan as a district judge for the U.S. District Court for the Southern District of Indiana (1987); and from President George W. Bush as a circuit judge for the U.S. Court of Appeals for the Seventh Circuit (2007). ${ }^{1}$ Yet these appointments are just one indication of how well-regarded Judge Tinder is, for the attorneys and case participants he worked with also recognize his outstanding contributions to the practice of law. His contributions resonate throughout the Southern District of Indiana, from the start of his career until his retirement from the U.S. Court of Appeals for the Seventh Circuit in October 2015. ${ }^{2}$

In surveying local attorneys and former colleagues for their memories of Judge Tinder during his time as U.S. Attorney and on the bench, a few notable traits came to the forefront: his insistence that justice be done; his civility and kindness; and his enthusiasm for mentoring young lawyers. Scott Shockley, now with DeFur Voran, recalled the following anecdote that illustrates how Judge Tinder put the pursuit of justice on a high plane:

In 1984, I was an assistant U.S. attorney when John Daniel Tinder was appointed U.S. Attorney by President Reagan. I had been working furiously on an investigation and prosecution of a prominent

* Judge, U.S. District Court, Southern District of Indiana. B.A., 1975, Drake University; J.D., 1980, George Mason University School of Law. Chief Judge Young and Judge Tinder served together on the District Court for nine years. Special thanks to Kathryn Sullivan, career law clerk to Chief Judge Young, Doria Lynch, District Court Public Information Officer, and Laura A. Briggs, Clerk of Court.

1. History of the Federal Judiciary, FED. JUD. CTR., http://www.fjc.gov/servlet/ nGetInfo?jid=2392\&cid=999\&ctype $=$ na\&instate=na [https://perma.cc/9FDG-45C3] (last visited Mar. 25, 2016). Among Hoosiers, Judge Tinder's three presidential appointments are exceeded by only Walter Q. Gresham, who received five: district judge for the District of Indiana (1869); Postmaster General (1883); Secretary of the Treasury (1884); circuit judge for the Seventh Circuit (also 1884); and Secretary of State (1893). Biographies of the Secretaries of State: Walter Quintin Gresham, U.S. DEP'T STATE, https://history.state.gov/departmenthistory/people/gresham-walterquintin [https://perma.cc/H57B-KRZK] (last visited Mar. 25, 2016).

2. Judge Tinder began his legal career after graduating from the Indiana University Maurer School of Law in 1975. History of the Federal Judiciary, supra note 1. Having clerked at the Office of the U.S. Attorney for the Southern District of Indiana while in law school, he was hired as an assistant U.S. attorney and continued in that capacity until 1977. Id. While also working in private practice (1977-1984), Judge Tinder served as a public defender in the Marion County Criminal Court (1977-1978) then acted as the Chief Trial Deputy for the Marion County Prosecutor's Office (1979-1982), further rounding out his resume. Id. He also worked as an adjunct professor at the Indiana University School of Law (1980-1988). Id.

http://dx.doi.org/10.18060/4806.01112 
Indianapolis banker for Misapplication of Funds, and the banker had excellent counsel. The case featured some novel theories of the misapplication statute and was not an obvious conviction if tried. It was one of the first things I talked to U.S. Attorney Tinder about when he took office and he was very interested, but I thought maybe that was just showing the troops some courtesy. Much to my surprise, a short time later he indicated if the case was tried, he wanted to try it with me. I was astonished, because the common wisdom is elected or appointed prosecutors don't try cases - too much to lose if the case goes badly. I've always remembered this, because it showed me from the first week or so that I met him that he was a courageous trial lawyer at heart, and not someone interested in the office for its political stature. In fact, he was willing to risk that political stature to try a case, which was pretty cool to somebody like me in the trenches. ${ }^{3}$

Larry Mackey of Barnes and Thornburg also had the good fortune of working with Judge Tinder during his tenure as U.S. Attorney. Mr. Mackey noted:

It wasn't long after John Tinder invited me to be an assistant U.S. attorney that he took the district court bench, but before he departed he gave me an assignment which would shake the local judiciary. Marion Superior Court Judge Michael Dugan was a popular jurist and votegetter but drew the attention of the Star with a series of court appointments to friends and political supporters. John handed me the newspaper accounts and instructed: Go find the truth. A few years later Dugan, still a sitting Marion County Judge, was indicted on corruption charges and later convicted by a jury and sentenced to 18 years in prison. John Tinder, the public servant, has always had a laser sharp eye and exquisite instinct for finding and protecting the public's interests. ${ }^{4}$

Once he became a district judge, Judge Tinder was still widely recognized for his insistence on getting things right. Ken Falk, Legal Director of the ACLU of Indiana, remembered a case that still resonates today:

A number of years ago a senior in high school contacted the ACLU of Indiana office on a Thursday. The student was a pre-operative transsexual (male to female) and had been taking hormones, I believe, during high school and had been wearing blouses and makeup to school. For some reason the school system was refusing to allow the student to wear a dress to the prom. The prom was on Friday evening. I spent Thursday night drawing up the case seeking injunctive relief only and writing a preliminary injunction memo that, I am sure, was not prizeworthy. We filed the case on Friday morning and Judge Tinder held a

3. Email from Scott E. Shockley, Partner, Defur Voran LLP, to Richard L. Young, Chief Judge, U.S. Dist. Court for the S. Dist. of Ind. (Jan. 13, 2016, 4:02 PM) (on file with author).

4. Email from Larry A. Mackey, Partner, Barnes \& Thornburg LLP, to Richard L. Young, Chief Judge, U.S. Dist. Court for the S. Dist. of Ind. (Jan. 12, 2016, 8:21 AM) (on file with author). 
hearing Friday afternoon. We had some testimony and oral argument and must have ended around 3:00. At that point Judge Tinder went back into his chambers for more than an hour and did further research before he came out and rendered a detailed oral decision. Remember, the prom was, at that point, just hours away and the losing party was not going to get a helicopter and fly to the Seventh Circuit to seek further review. Whatever the Judge decided would end the case. He did not view this as a trivial case and he did not hurry. He took the time and effort to get to what he believed to be a just and reasoned decision.

The ironic thing is that when Judge Tinder came back into the courtroom he said-jokingly - that he hoped he would be remembered for something more than this case. Of course he is-but the lesson I drew from it, about a jurist who was concerned only with making a decision that he deemed to be correct, who was willing to work on the case beyond what the lawyers had presented, and who would not be rushed in to making a decision, is something I remember all these years later. ${ }^{5}$

Judge Tinder granted the student's request for injunctive relief. His careful consideration of the matter, on an emergency basis, allowed the student to leave the courthouse in time to dress for the prom.

James H. Voyles of Voyles Zahn \& Paul related the following about an unusual criminal trial before Judge Tinder:

My partner, Dennis Zahn, and I tried a federal HUD fraud trial in front of Judge Tinder by jury. There were 2 defendants in the case, a man and a woman; Mr. Zahn and I represented the man, and the woman had her own counsel. After the government had rested their case, we moved for a dismissal of the government's case pursuant to Rule 29 of the Federal Rules of Criminal Procedure. Judge Tinder took the matter under advisement. We then presented no evidence, on behalf of our client, nor did the other defense attorney on behalf of his client, and both sides rested.

We then renewed, on behalf of our client, our motion at the close of the entire case. Judge Tinder again took our motion under advisement and sent the case to the jury. After a few hours of deliberations, the jury returned their verdicts as to both defendants, finding them guilty of all the charges. Our client was devastated with the results. The Court then thanked the jury for their work and excused them, but had the clients and counsel remain in the courtroom. After the jury had left, Judge Tinder granted our motion and found our client not guilty, but let the verdict stand as to the female defendant.

This was the first and only time in my federal practice career that I've

5. Email from Ken Falk, Legal Dir., Am. Civil Liberties Union of Ind., to Richard L. Young, Chief Judge, U.S. Dist. Court for the S. Dist. of Ind. (Jan. 7, 2016, 10:54 AM) (on file with author). 
had that happen. Our client went from devastation to jubilation in just a few minutes. It was then that I found out what a fine judge my friend John Tinder had become. It is always with a little trepidation when the former United States Attorney becomes the judge of a case. The clients asked, "Didn't he use to prosecute these cases?" However, in Judge Tinder's case (and as with others on the bench in our district who have taken this route to judicial office), there is certainly no need to worry about any of them not being fair and impartial. ${ }^{6}$

Judge Tinder is also widely regarded for his civility and kindness. From inviting counsel into chambers during trial recesses to enjoy a snack and conversation about family, baseball, and world events, to going off the record during a trial to announce the outcome of an NCAA basketball tournament game of interest to case participants, to allowing those present for a hearing on September 11, 2001, to watch events unfold on a small television in his chambers' breakroom, Judge Tinder put forth extra effort to make attorneys and case participants feel at ease. ${ }^{7}$ The following story from Debra Miller of Miller \& Fisher, LLC is perhaps the most illustrative of Judge Tinder's compassion:

Judge Tinder wrote an opinion in 1993 in the case of Vigo County Republican Cent. Comm. v. Vigo County Comm'rs, 834 F. Supp. 1080. My grandfather, John Hanley [working at the behest of the County Commissioners - the defendant in the case], testified at the trial. He was 80 years old. Judge Tinder [found in favor of the plaintiff, the Vigo County Republican Central Committee and] included the following footnote in the opinion: "It should be noted that this court intends no criticism of Mr. Hanley, a native of Vigo County since his birth in 1912. $\mathrm{He}$ is a bright and diligent man who carries in his head a wealth of historical knowledge regarding the political and geographic boundaries of that county. He performed his duties on this matter exactly as he was directed by the Commissioners. The court has no doubt that Mr. Hanley could have reached the same level of equality among the districts as the Plaintiffs' Plan if he had been assigned that mission. Most remarkably, Mr. Hanley performed his work with only the benefit of a pencil, a note pad, and a few maps - no high-tech computers were necessary for him."

I don't know why Judge Tinder included the footnote. He didn't have to. It didn't affect the result, but it meant the world to my grandfather. To put it into context, my father (my grandfather's oldest son and namesake) had died very suddenly and unexpectedly of a heart attack the year before at age 54. My grandfather never recovered from that grief. My grandfather, himself, died less than 3 years after my father's death and

6. Email from James H. Voyles, Jr., Voyles Zahn \& Paul, to Richard L. Young, Chief Judge, U.S. Dist. Court for the S. Dist. of Ind. (Jan. 14, 2016, 11:19 AM) (on file with author).

7. Many thanks to attorneys Tom Funk, John Kautzman, Mark Inman, and part-time U.S. Magistrate Judge Craig M. McKee for sharing these recollections. 
less than 2 years after Judge Tinder's opinion was written. That footnote was one of the few high points of the most difficult time of my grandfather's life. When we went through my grandfather's things upon his death, we found a copy of Judge Tinder's opinion. It was one of the things he had kept and held onto. ${ }^{8}$

While Judge Tinder's pursuit of justice and caring demeanor are remarkable, his most lasting contribution to the legal field came through his efforts to teach young lawyers. Kathleen DeLaney of DeLaney \& DeLaney LLC noted:

Judge Tinder made time to mentor and train young lawyers, particularly in trial advocacy skills. Early in my career, he invited me to accept appointment as pro bono trial counsel for a pro se litigant who had survived summary judgment in a civil rights case against the police. After the jury returned its verdict, the judge invited all of the lawyers to meet with the jurors to get feedback and constructive criticism. Later, after the case had been settled, Judge Tinder asked his court reporter to prepare a rough trial transcript, which he carefully reviewed and annotated. Then he sat down with me to review the annotated transcript, providing a mini-course on trial techniques. The learning experience was invaluable, but he didn't stop there. He used the case and the verdict as the basis for nominating the young lawyer for a pro bono award. ${ }^{9}$

John Kautzman of Ruckelshaus, Kautzman, Blackwell, Bemis \& Hasbrook had a similar experience.

After my first solo federal jury trial - which happened to be in front of Judge Tinder - I went back to my office gratified by a verdict in our favor. Approximately a month later (ensuring no appeals) I got a call from his secretary saying the judge wanted to see me. Judge Tinder then invited me into his chambers, told me very encouraging words about my still developing trial skills, and showed me office memorabilia and his Dodger-Town baseball cards. Needless to say, he put me on cloud nine and even further ignited my passion for litigators and lawyers in general. He quite simply impressed upon me the nobility and art of our profession and instilled in me the sacred obligation to be a good steward of that legacy going forward. ${ }^{10}$

8. Email from Debra H. Miller, Miller \& Fisher, LLC, to Richard L. Young, Chief Judge, U.S. Dist. Court for the S. Dist. of Ind. (Jan. 13, 2016, 12:01 PM) (on file with author) (quoting Vigo Cty. Republican Cent. Comm. v. Vigo Cty. Comm'rs, 834 F. Supp. 1080, 1086 n.11 (S.D. Ind. 1993)).

9. Email from Kathleen DeLaney, DeLaney \& DeLaney, LLC, to Richard L. Young, Chief Judge, U.S. Dist. Court for the S. Dist. of Ind. (Jan. 7, 2016, 2:29 PM) (on file with author).

10. Email from John Kautzman, Ruckelhaus, Kautzman, Blackwell, Bemis \& Hasbrook, to Richard L. Young, Chief Judge, U.S. Dist. Court for the S. Dist. of Ind. (Jan. 13, 2016, 11:40 PM) (on file with author). 
Judge Tinder also took steps to teach young lawyers even the most basic elements of good courtroom practice. As Scott Shockley described:

I was in a trial in Judge Tinder's court, examining a witness and, I thought, doing a decent job, staying within the proper boundaries and all that. So I was a little surprised and worried when the Judge said "Mr. Shockley, approach the bench" which, unless one has asked to do so, isn't a good sign. So I walked up there and the Judge leaned forward and asked me with a straight face if he could buy the change in my pocket. It took a while to register, what with being preoccupied with the case and all, that I had been absent-mindedly jingling coins when I would put my hand in my pocket, obviously to the point of being loud enough to be a distraction. I tried to keep my best poker face and went back to the podium, kept my hands free, and emptied those pockets as soon as I sat down, and never put a dime in them again. ${ }^{11}$

Lawyers recalled a number of other memories of practicing before Judge Tinder, from now-part-time U.S. Magistrate Judge Craig M. McKee's recollections of meeting with jurors under Judge Tinder's supervision after trials to Scott Shockley's memory of the announcement of a not guilty verdict that led to cheers from the gallery and an ensuing gavel strike by Judge Tinder that resulted in the head of the gavel flying off and sailing through the well of the courtroom.

Throughout his illustrious career as a lawyer, judge, and mentor, Judge Tinder has retained a good sense of humor, strong ties to the community, and an approachability that makes him unique. But we will remember him most for his respect for the rule of law in all its facets - from the litigants and lawyers who appeared before him to the opinions that he wrote - to his willingness to mentor young lawyers, and his kind judicial demeanor. This legacy is a gift to our profession.

11. Email from Scott E. Shockley to Richard L. Young, supra note 4. 